\title{
Alcohol degradation and bromsulphthalein metabolism in acute alcoholic liver disease
}

\author{
PATRICIA WILKINSON, DENIS M. O'DAY, AND JAMES G. RANKIN \\ From the University of Melbourne Department of Medicine, St Vincent's Hospital, Melbourne, \\ Australia
}

\begin{abstract}
A very early consequence of excessive alcohol ingestion is a reduction in the capacity of the human liver to store injected bromsulphthalein (BSP) at concentrations above those in the plasma (Wilkinson, O'Day, Breen, and Rankin, 1968). This biochemical defect, which is unrelated to morphological changes in the liver, occurs without alteration in biliary excretion of the dye, and is reversible with abstinence. The defect appears to be a direct toxic effect of ethanol for it is related to the time since alcohol was last drunk, but not to the type of alcoholic beverage nor to the patient's nutritional state.
\end{abstract}

The mechanism by which ethanol produces this biochemical abnormality is not clear. Possible explanations include changes in hepatic blood flow, alterations at the cell boundary, or damage to intracellular enzymes. Ethanol has been shown to produce ultrastructural changes in the livers of alcoholic (Rubin and Lieber, 1967) and non-alcoholic volunteers (Rubin and Lieber, 1968) independent of nutritional factors. Among the cytoplasmic organelles consistently altered was the smooth endoplasmic reticulum, which is known to be a primary site for drug metabolism (Conney, 1967). Damage to this structure could thus lead to altered BSP metabolism.

Ethanol too is metabolized by the liver cell, though by pathways which are probably quite distinct from those of BSP elimination. Any interrelation or interdependence between the metabolism of the two substances would suggest some common mechanism. This paper reports a study in which ethanol degradation and BSP metabolism were measured simultaneously in a group of patients with acute alcoholic liver disease. It was hoped that such a study might provide further information, not only about the nature of the storage defect caused by excessive drinking, but also about pathways of normal BSP metabolism. Patients with established cirrhosis were excluded since permanent changes in both BSP metabolism (Wheeler, Meltzer, and Bradley, 1960; Preisig, Williams, Sweeting, and Bradley, 1966) and alcohol degradation (Bauer, 1948-49; Bernstein and Staub,
1948; Lieberman, 1963) have been found in advanced liver disease.

\section{METHODS}

PATIENTS STUDIED Sixteen men aged between 33 and 57 years were studied. All had been drinking excessive amounts of :alcohol until shortly before admission to St Vincent's Hospital, Melbourne, for treatment of alcoholism. In no patient was there any history or clinical evidence of congestive cardiac failure, and none was clinically jaundiced. In eight patients a smooth, firm liver was palpable.

Serum glutamic oxaloacetic transaminase (SGOT) values were either normal or only modestly raised, the highest value being 62 Sigma Frankel units per ml. Percutaneous needle biopsies of liver were obtained from all patients and in none was there any histological evidence of cirrhosis. Four patients had normal liver biopsies; five had fatty infiltration only; six had acute alcoholic hepatitis, that is, parenchymal cell necrosis and inflammatory response as well as fatty change; and one had patchy cell necrosis without fat.

The patients were studied after a period of alcohol withdrawal which varied from two to 21 days. No medication was given during the period of study apart from oral chlordiazepoxide in doses of $\mathbf{4 0}$ to $100 \mathrm{mg} /$ day and oral or intramuscular vitamin supplements.

The clinical and laboratory findings of the patients are summarized in Table I.

PROCEDURE The patients were studied after an overnight fast, within $\mathbf{4 8}$ hours of liver biopsy.

Measurements of alcohol degradation and of relative storage capacity and biliary excretion maximum for BSP (SBSP and TmBSP) were combined in a single procedure. Each patient first received a measured dose of ethanol by constant travinenous infusion controlled by a Harvard multispeed pump. It was administered through an indwelling catheter inserted into one antecubital vein. The ethanol was immediately followed by two infusions of a BSP solution. Samples of venous blood were collected from the opposite arm into heparinized tubes at suitable intervals for the estimation of whole blood ethanol and plasma BSP concentrations. At the end of the second BSP infusion the plasma volume was estimated using ${ }^{131}$ I-labelled human albumin. 
T A B L E I

$\begin{array}{lllll}\text { Patient No. Age }(\mathrm{yr}) & \text { Weight }(\mathrm{kg}) \quad \begin{array}{l}\text { Palpable } \\ \text { Liver }\end{array} & \begin{array}{l}\text { SGOT } \\ (\mathrm{SF} \text { units } / \mathrm{ml})\end{array} & \text { Histology of Liver Biopsy }\end{array}$

\begin{tabular}{|c|c|c|c|c|c|c|}
\hline 1 & 46 & $68 \cdot 6$ & + & 54 & Acute alcoholic hepatitis & 5 \\
\hline 2 & 42 & $60 \cdot 4$ & + & 30 & Normal & 6 \\
\hline 3 & 49 & $66 \cdot 3$ & 0 & 18 & Acute alcoholic hepatitis & 6 \\
\hline 4 & 57 & $63 \cdot 4$ & + & 42 & Fatty infiltration & 3 \\
\hline 5 & 45 & $121 \cdot 0$ & + & 57 & Acute alcoholic hepatitis & 3 \\
\hline 6 & 53 & $61 \cdot 5$ & $\mathbf{0}$ & 21 & Acute alcoholic hepatitis, early portal fibrosis & 15 \\
\hline 7 & 57 & $68 \cdot 0$ & $\mathbf{0}$ & 16 & Normal & 8 \\
\hline 8 & 52 & 52.9 & 0 & 26 & Acute alcoholic hepatitis, early portal fibrosis & 6 \\
\hline 9 & 43 & $72 \cdot 6$ & + & 62 & Fatty infiltration & 2 \\
\hline 11 & 33 & $62 \cdot 6$ & $\mathbf{0}$ & 22 & Normal & 7 \\
\hline 12 & 47 & $85 \cdot 5$ & $\mathbf{0}$ & 29 & Fatty infiltration & 14 \\
\hline 13 & 35 & $61 \cdot 9$ & 0 & 23 & Fatty infiltration & 8 \\
\hline 14 & 42 & $58 \cdot 6$ & 0 & 22 & Patchy cell necrosis & 15 \\
\hline 15 & 55 & $77 \cdot 0$ & + & 41 & Fatty infiltration & 9 \\
\hline 16 & 35 & $71 \cdot 7$ & 0 & 26 & Normal & 21 \\
\hline
\end{tabular}

In three patients the BSP infusions and plasma volume estimation were repeated after 24 or $\mathbf{4 8}$ hours without a prior alcohol infusion.

MEASUREMENT OF ETHANOL DEGRADATION A measured dose of between 25 and $50 \mathrm{~g}$ of absolute ethanol in approximately $400 \mathrm{ml}$ water was infused at a constant rate over a timed period of about 30 minutes. Blood samples were taken at $60,90,120$, and 150 minutes after the commencement of the infusion, and whole blood ethanol concentrations of those samples were determined in duplicate by Öbrink's (1955) modification of the Conway microdiffusion method (1950). In the earlier estimations excess dichromate remaining after oxidation of the ethanol was measured titrimetrically, but later it was measured spectrophotometrically as recommended by Powell and Ellam (1964).

The method described by Lieberman (1963) was used to calculate degradation rates. The rate of disappearance of ethanol from the blood (m) and the whole blood ethanol concentration at the theoretical zero time $\left(\mathrm{C}_{0}\right)$ were calculated mathematically from the whole blood concentrations. Both were expressed as milligrams per 100 grams of whole blood.

Widmark's factor (r), the ratio of whole blood ethanol concentration to whole blood concentration, was calculated for each patient from the formula

$$
\mathrm{r}=\frac{\mathrm{mg} \text { ethanol infused }}{\text { body weight in } \mathrm{kg}} \times \mathrm{C}_{\mathrm{o}}
$$

The absolute rate of ethanol degradation expressed as milligrams per kilograms whole body weight per hour was then equal to $\mathrm{m} \times 10 \times \mathrm{r}$.

MEASUREMENT OF SBSP AND TmBSP Immediately after the ethanol infusion $S_{B S P}$ and $T m_{B S P}$ were measured by the double infusion technique of Wheeler et al (1960). Bromsulphthalein was first infused at a constant rate to achieve a rising plasma concentration. After an equilibration period of 30 minutes five blood samples were taken at five-minute intervals. For the second infusion period the rate was slowed to produce a falling plasma concentration and after a further 30 minutes five more samples were taken, again at five-minute intervals. Plasma BSP concentrations of these samples were estimated in duplicate by the method of Seligson, Marino, and Dodson (1957).

The rate of change of plasma BSP $\left(P_{1}\right.$ and $\left.P_{2}\right)$ was calculated mathematically for the two infusion periods and from them and the plasma volume (PV) S S Tm $\mathrm{BSP}$ were calculated using the formula

$$
\mathbf{I}=\mathbf{T m}+\mathbf{P}(\mathbf{P V}+\mathbf{S})
$$

where $\mathrm{I}=$ amount of BSP infused. $\mathrm{S}_{\mathrm{BSP}}$ was expressed as milligrams of dye stored per milligrams per $100 \mathrm{ml}$ of plasma concentration $(\mathrm{mg} / \mathrm{mg} / 100 \mathrm{ml})$ and TmBSP as milligrams of dye excreted per minute $(\mathrm{mg} / \mathrm{min})$.

\section{RESULTS}

The infusion of ethanol immediately before BSP did not affect the hepatic elimination of BSP in terms of values for $S_{B S P}$ and $T m_{B S P}$ in the three patients studied twice (Table II).

\section{T A B L E I I}

COMPARISON OF RELATIVE STORAGE CAPACITY (SBSP) AND BILIARY EXCRETION MAXIMUM (TMBSP) FOR BROMSULPHTHALEIN WITH AND WITHOUT SIMULTANEOUS ETHANOL

\begin{tabular}{|c|c|c|c|c|}
\hline \multirow[t]{2}{*}{ Patient No. } & \multicolumn{2}{|c|}{$S_{\mathrm{BSP}}(\mathrm{mg} / \mathrm{mg} / 100 \mathrm{ml})$} & \multicolumn{2}{|c|}{$T m_{\mathrm{BSP}}(\mathrm{mg} / \mathrm{min})$} \\
\hline & $\begin{array}{l}\text { With } \\
\text { Ethanol }\end{array}$ & $\begin{array}{l}\text { Without } \\
\text { Ethanol }\end{array}$ & $\begin{array}{l}\text { With } \\
\text { Ethanol }\end{array}$ & $\begin{array}{l}\text { Without } \\
\text { Ethanol }\end{array}$ \\
\hline $\begin{array}{r}2 \\
8 \\
12\end{array}$ & $\begin{array}{l}11 \\
20 \\
44\end{array}$ & $\begin{array}{l}11 \\
14 \\
42\end{array}$ & $\begin{array}{r}9 \cdot 3 \\
8 \cdot 2 \\
10 \cdot 4\end{array}$ & $\begin{array}{r}9 \cdot 7 \\
9 \cdot 6 \\
11 \cdot 2\end{array}$ \\
\hline
\end{tabular}
INFUSION

The results of the combined measurement of BSP and ethanol metabolism are arranged in Table III in order of increasing $S_{\text {BSP }}$ values. Values for $S_{\text {BSP }}$ ranged from as little as $2 \mathrm{mg} / \mathrm{mg} / 100 \mathrm{ml}$ to normal, 
T A B L E I I I

ETHANOL DEGRADATION, RELATIVE STORAGE CAPACITY (S BSP), AND BILIARY EXCRETION MAXIMUM (TMBSP) FOR BROMSULPHTHALEIN IN MEN WITH ACUTE ALCOHOLIC LIVER DISEASE

\begin{tabular}{|c|c|c|c|}
\hline \multirow{2}{*}{$\begin{array}{l}\text { Patient } \\
\text { No. }\end{array}$} & \multirow{2}{*}{$\begin{array}{l}S_{\mathrm{BSP}} \\
(\mathrm{mg} / \mathrm{mg} / 100 \mathrm{ml})\end{array}$} & \multirow{2}{*}{$\begin{array}{l}T m_{\mathrm{BSP}} \\
(\mathrm{mg} / \mathrm{min})\end{array}$} & Ethanol Degradation \\
\hline & & & $\begin{array}{ll}(\mathrm{mg} / 100 \mathrm{~g} & (\mathrm{mg} / \mathrm{kg} \text { body } \\
\text { whole blood } / \mathrm{hr}) & \mathrm{wt} / \mathrm{hr})\end{array}$ \\
\hline
\end{tabular}
whole blood/hr) wt/hr)

\begin{tabular}{rrrrr}
\hline 1 & 2 & $9 \cdot 6$ & $43 \cdot 3$ & 141 \\
2 & 11 & $9 \cdot 3$ & $21 \cdot 0$ & 127 \\
3 & 13 & $13 \cdot 1$ & $20 \cdot 8$ & 130 \\
4 & 14 & $9 \cdot 6$ & $32 \cdot 5$ & 165 \\
5 & 17 & $5 \cdot 7$ & $57 \cdot 6$ & 151 \\
6 & 18 & $14 \cdot 1$ & $35 \cdot 4$ & 175 \\
7 & 19 & $13 \cdot 2$ & $11 \cdot 2$ & 101 \\
8 & 26 & $8 \cdot 2$ & $26 \cdot 4$ & 114 \\
9 & 24 & $13 \cdot 8$ & $29 \cdot 3$ & 122 \\
10 & 27 & $9 \cdot 8$ & $18 \cdot 3$ & 141 \\
11 & 34 & $6 \cdot 3$ & $35 \cdot 7$ & 178 \\
12 & 44 & $10 \cdot 4$ & $31 \cdot 8$ & 142 \\
13 & 46 & $12 \cdot 9$ & $19 \cdot 3$ & 129 \\
14 & 48 & $12 \cdot 0$ & $16 \cdot 0$ & 133 \\
15 & 60 & $11 \cdot 8$ & $38 \cdot 6$ & 119 \\
16 & 77 & $15 \cdot 1$ & $10 \cdot 8$ & 110 \\
& & Mean $28 \cdot 0 \pm 12 \cdot 6$ & Mean $136 \pm 23$
\end{tabular}

while TmBSP remained within the normal range. Values for normal men established by Preisig et al (1966) are $S_{\mathrm{BSP}}=69 \pm 17 \mathrm{mg} / \mathrm{mg} / 100 \mathrm{ml}$ and $T m_{B S P}$ $=9.6 \pm 1.9 \mathrm{mg} / \mathrm{min}$.

Alcohol degradation rates were not reduced. They varied from 10.8 to $57.6 \mathrm{mg} / 100 \mathrm{~g}$ whole blood/hr (mean $28.0 \pm 12.6$ ) or 101 to $178 \mathrm{mg} / \mathrm{kg}$ body weight/hr (mean $136 \pm 23$ ). These values agree well with those obtained by Asada and Galambos (1963) who intravenously administered ethanol (23.8 \pm $9 \cdot 3 \mathrm{mg} / 100 \mathrm{~g}$ whole blood/hr) and are slightly higher than those obtained by Bernstein and Staub (1948) and Lieberman (1963) $(107 \pm 16 \mathrm{mg} / \mathrm{kg}$ body weight/ $\mathrm{hr}$ and $98 \pm 12 \mathrm{mg} / \mathrm{kg}$ body weight/hr respectively) who administered ethanol orally.

\section{DISCUSSION}

It has been suggested that the alcoholic may have an increased tolerance for alcohol because of an increased hepatic metabolism of ethanol (Sherlock, 1968). The degradation rates for ethanol obtained in this study are higher than the normal ranges reported by Bernstein and Staub (1948) and Lieberman (1963). These authors administered ethanol orally, but Asada and Galambos (1963), who gave it intravenously to normal subjects, found rates comparable to those reported here for alcoholic patients. This suggests that our rates are normal for the intravenous route of administration, and that there has been no increase in the hepatic metabolism of alcohol in our patients.

It is apparent from our results that BSP metabolism is a very sensitive index of liver function in alcoholic liver disease. Severe depression of SBsP can coexist not only with normal microscopic appearances in the liver (Wilkinson et al, 1968) but also with normal rates of ethanol metabolism. This depression was not caused by competition or interference with BSP metabolism by the infused ethanol, since in the three patients studied twice $S_{\mathrm{BSP}}$ was not improved when it was measured again without a simultaneous infusion of ethanol.

Ethanol reaches the liver cell by way of the portal venous and hepatic arterial blood supply. As it is so readily diffusible it enters the cell rapidly and without difficulty. Inside the cell it is oxidized by means of the cytoplasmic enzyme alcohol dehydrogenase (ADH). The rate of oxidation is dependent not only on the rate of delivery of ethanol to the liver and on the activity of ADH in the liver cell, but also on the availability of nicotinamide adenine dinucleotide (Lieber, 1965).

By contrast BSP, which reaches the liver by the same route, enters the liver cell much less easily since it has a larger molecule and is bound to plasma albumin. Once inside the cell it is stored against a gradient between the cell and the plasma across the cell wall before being excreted in conjugated form into the bile (Wheeler et al, 1960). It is not known how the transfer of dye across the cell wall is effected, nor how the dye is stored against the hepatocyteplasma gradient. Furthermore, it is not clear whether conjugation with glutathione occurs during uptake, storage, or later. However, irrespective of whether the dye is stored in conjugated or unconjugated form, it seems likely that energy-dependent enzymic processes are involved. From our observations these must differ from those concerned with ethanol breakdown, since severe defects of bromsulphthalein storage can exist in patients who have normal rates of ethanol degradation.

The storage defect could result from damage to some intracellular enzymic process, but this would have to be distinct from the alcohol dehydrogenase system, which is in the matrix of the cytoplasm. Damage to microsomal enzymes is a possible explanation, for structural changes in the endoplasmic reticulum of liver cells have been observed very early in the development of acute alcoholic liver disease (Rubin and Lieber, 1967). Similar changes have also been produced in the livers of young non-alcoholic volunteers who were given large amounts of ethanol with adequate diets (Rubin and Lieber, 1968).

Alternatively the defect could well be located at the hepatic cell wall. If this structure were altered in some way the easily diffusible ethanol would be able to enter the liver cell unimpeded but BSP uptake might be delayed. These possibilities can be investigated further by studying in alcoholic patients the 
elimination of other drugs handled by the liver, simultaneously with the measurement of BSP metabolism.

\section{SUMMARY}

It has been shown previously that prolonged excessive consumption of ethanol is associated with a reversible depression of bromsulphthalein storage (S $\left.\mathrm{S}_{\mathrm{BSP}}\right)$. In order to explore this abnormality further, measurements of the rate of alcohol degradation and the relative storage capacity $\left(\mathrm{S}_{\mathrm{BSP}}\right)$ and biliary excretion maximum for BSP were combined in a single infusion procedure in 16 male patients who had recently been drinking excessive amounts of alcohol. Needle biopsies of the liver were performed on all patients and none was found to have histological evidence of cirrhosis. SBSP and TmBSP estimations were repeated within $\mathbf{4 8}$ hours in three patients without simultaneous ethanol infusion.

A wide range of $S_{\mathrm{BSP}}$ values, varying from 2 to $77 \mathrm{mg} / \mathrm{mg} / 100 \mathrm{ml}$, were obtained. The BSP values and alcohol degradation rates were within normal limits. No correlation was found between $S_{B S P}$ and alcohol degradation rate; values for $\mathrm{S}_{\mathrm{BSP}}$ and $\mathrm{Tm}_{\mathrm{BSP}}$ did not change when BSP was infused without ethanol.

Possible sites in the liver cell for the defect of bromsulphthalein storage which occurs in acute alcoholic liver disease are discussed.

We are indebted to Miss Patricia Cockburn, Miss Helen Malone, and Miss Wilma Huygens for technical assistance.
One of us (P.W.) held a Roche research fellowship during part of the study and another (D.M. O'D.) was the John Hayden research fellow in the University of Melbourne Department of Medicine, St Vincent's Hospital.

\section{REFERENCES}

Asada, M., and Galambos, J. T. (1963). Liver disease, hepatic alcohol dehydrogenase activity, and alcohol metabolism in the human. Gastroenterology, 45, 67-72.

Bauer, H. A. (1948-49). Der vereinfachte Alkoholtestals Leberfunktionprüfung. Gastroenterologia (Basel), 74, 341-348.

Bernstein, A., and Staub, H. A. (1948). Zur funktionellen Leberprüfung mit Alkohol. Helv. med. Acta, 15, 494-498.

Conney, A. H. (1967). Pharmacological implications of microsomal enzyme induction. Pharmacol. Rev., 19, 317-366.

Conway, E. J. (1950). Alcohol in body fluids. In Microdiffusion Analysis and Volumetric Error, 3rd ed., pp. 250-253. Crosby Lockwood, London.

Lieber, C. S. (1965). Alcohol and the liver. Progr. Liver Dis., 2 , 134-135.

Lieberman, F. L. (1963). The effect of liver disease on the rate of ethanol metabolism in man. Gastroenterology, 44, 261-266.

Obrink, K. J. (1955). A modified Conway unit for microdiffusion analysis. Biochem. J., 59, 134-136.

Powell, F. J. N., and Ellam, B. (1964). Photometric procedures for the determination of dichromate. Application to alcohol by means of the Conway unit. Clin. chim. Acta, 10, 472-474.

Preisig, R., Williams, R., Sweeting, J., and Bradley, S. E. (1966). Changes in sulfobromophthalein transport and storage by the liver during viral hepatitis in man. Amer. J. Med., 40, 170-183.

Rubin, E., and Lieber, C. S. (1967). Early fine structural changes in the human liver induced by alcohol. Gastroenterology, 52, 1-13.

(1968). Alcohol-induced hepatic injury in nonalcoholic volunteers. New Engl. J. Med., 278, 869-876.

Seligson, D., Marino, J., and Dodson, E. (1957). Determination of sulfobromophthalein in serum. Clin. Chem., 3, 638-645.

Sherlock, S. (1968). Drugs and the liver. Brit. med. J., 1, 227-229.

Wheeler, H. O., Meltzer, J. I., and Bradley, S. E. (1960). Biliary transport and hepatic storage of sulfobromophthalein sodium in the unanaesthetized dog in normal man, and in patients with hepatic disease. J. clin. Invest., 39, 1131-1144.

Wilkinson, P., O'Day, D. M., Breen, K. J., and Rankin, J. G. (1968) Bromsulphthalein metabolism in acute alcoholic liver disease. Gut, 9, 707-711. 